\title{
Pengelolaan Sarana Dan Prasarana Di Sekolah Dasar Muhammadiyah Kota Padang
}

\author{
Armalena \\ Universitas Muhammadiyah Sumatera Barat \\ Email: lena49075@gmail.com \\ Diterima: November 2019; Dipublikasikan Januari 2020
}

\begin{abstract}
ABSTRAK
Tujuan yang ingin dicapai dalam penelitian ini adalah untuk memperoleh dan mendapatkan informasi mengenai pengelolaan saana dan pasarana SD Muhammadiyah di Kota Padang. Penelitian ini bersifat analisis deskriptif dengan jumlah populasi seluruh guru kelas sekolah dasar Muhammadiyah di kota Padang yang berjumlah 77 orang. Alat pengumpulan data yang digunakan adalah angket model skala Likert dengan alternatif jawaban yaitu selalau (SL), sering (SR), kadang-kadang (KDG), jarang (JR), dan tidak pernah (TP). Hasil penelitian menunjukkan bahwa: Pengelolaan sarana dan prasarana berada pada $72,42 \%$. Artinya kriteria interpretasi skor berada pada kesimpulan baik. Namun, pada faktanya banyak yang tidak sesuai dengan hasil yang diperoleh dari angket tersebut. Hal ini karena guru dan pegawai sekolah kurang berlaku jujur dalam mengisi angket yang diberikan.
\end{abstract}

Kata Kunci: pengelolaan, sarana, prasarana, SD Muhammadiyah.

\begin{abstract}
The aim of this research is to obtain and obtain information about the management of Saana and Pasar Muhammadiyah Elementary Schools in Padang City. This research is a descriptive analysis with a total population of all Muhammadiyah elementary school class teachers in the city of Padang, amounting to 77 people. The data collection tool used was a Likert scale questionnaire with alternative answers, namely always (SL), often (SR), sometimes (KDG), rarely (JR), and never (TP). The results showed that: Management of facilities and infrastructure was at $72.42 \%$. This means that the score interpretation criteria are in good conclusions. However, in fact many of them do not match the results obtained from the questionnaire. This is because teachers and school employees are not honest in filling out the questionnaire given.
\end{abstract}

Keywords: management, facilities, infrastructure, Muhammadiyah Elementary School 


\section{PENDAHULUAN}

Muhammadiyah didirikan oleh K.H. Ahmad Dahlan pada tanggal 8 Zulhijjah $1330 \mathrm{H}$, bertepatan pada tanggal 18 November $1912 \mathrm{M}$. Muhammadiyah merupakan sebuah gerakan Islam dan dakwah, berakidah Islam dan bersumber pada al-Qur'an dan sunnah serta bertujuan menegakkan dan menjunjung tinggi agama Islam sehingga terwujud masyarakat utama, adil dan makmur di bawah naungan ridha Allah. Gerakan Muhammadiyah dikenal luas sebagai gerakan yang sangat dipengaruhi oleh gagasan modern dan reformis yaitu untuk memurnikan ajaran Islam di Indonesia dari praktekpraktek khurafat tradisional yang tidak Islami. Untuk memajukan program pembaruannya, Muhammadiyah menyerukan agar kaum muslimin kembali kepada Islam yang murni. Setiap gerak dan kiprah Muhammadiyah baik dalam bidang dakwah, tajdid (pembaruan), pendidikan dan sosial kemasyarakatan dimaksudkan untuk mencapai tujuan di atas. Seluruh gerakan dan segenap amal usahanya merupakan perjuangan yang tidak kenal henti dalam merealisasikan tujuan mulia dan suci itu (Yunus, 1930:268).

Muhammadiyah dengan perangkat organisasinya, kepemimpinan dan amal usaha yang sedemikian besar tersebar luas diseluruh pelosok tanah air dan lapisan masyarakat. Saat ini telah menjadi suatu gerakan dan komunitas tersendiri. Demikian halnya dengan sejumlah potensi ekonomi, pendidikan, sosial budaya serta potensi keagamaannya. Tetapi pada kenyataannya, seperti yang penulis alami sendiri ketika menempuh pendidikan Sekolah Dasar Muhammadiyah (SDM) 7 Air Mati Kecamatan Padang Timur Kota Padang pada tahun 1987-1993, penullis tidak mendapatkan pelajaran yang menjadi plusnya pendidikan Muhammadiyah ini. Hal ini juga menurut asumsi sementara penulis terjadi di sekolah-sekolah pendidikan yang dikelola oleh Muhammadiyah ditempat lain di Kota Padang, termasuk tingkat Sekolah Dasar (SD).

Sekaitan dengan hal di atas, jika diamati secara langsung bahwa pendidikan yang dikelola oleh amal usaha Muhammadiyah yang bergerak di bidang pendidikan saat ini mengalami berbagai macam kendala. Di antara kendala itu adalah karena kurangnya halhal yang sangat diperlukan oleh sebuah lembaga pendidikan seperti sarana dan prasarana dari sekolah itu sendiri serta elemen-elemen yang berhubungan dengan pendidikan tersebut. Hal itulah yang akan dikupas dalam tulisan ini, yaitu tentang pengelolaan sarana dan prasarana SD Muhammadiyah di Kota Padang.

\section{Sejarah Muhammadiyah}

\section{TINJAUAN PUSTAKA}

Sebelum berdirinya Muhammadiyah, sebenarnya telah banyak dijumpai usaha dalam bidang penyiaran agama Islam dengan cara baru oleh K.H. Ahmad Dahlan. K.H. Ahmad Dahlan ditengah-tengah masyarakat lebih dikenal dengan sebutan Khatib Amin. Hal ini adalah karena jabatannya sebagai khatib di mesjid besar Yogyakarta. Selanjutnya, untuk mengukuhkan usaha dan pergerakannya itu diperlukan suatu perserikatan yang terencana dan terorganisir yang mampu bergerak dan beramal dengan sebaik-baiknya. Setelah bermusyawarah dengan para sahabat dan murid-muridnya tentang hal ini, maka disepakatilah Sekolah Guru (Kweek School) sebagai tempat untuk membentuk suatu organisasi yang modern dan mampu melaksanakan mekanisme kerja dan amal usaha secara baik yang kemudian dikenal dengan sebutan "Muhammadiyah". Selanjutnya, penulis akan menjelaskan sejarah berdirinya Muhammadiyah di Padang. Penelusuran tentang sejarah berdirinya Muhammadiyah di Padang dapat diketahui melalui manuskrip yang ditulis oleh Engku A. Bakar M yang ditulis ulang oleh Ali Imran Yunus (Sekretaris Pimpinan Daerah Muhammadiyah periode 2000-2005). Dalam manuskrip tersebut 
dijelaskan bahwa berdirinya Muhammadiyah di Padang berawal dari keberangkatan tiga orang tokoh yaitu Pakih Salih, Syukur Bakhri, dan Ismael Syamsudin ke Bukuttinggi untuk mengikuti rapat Muhammadiyah. Setiap hasil rapat yang diadakan di Bukuttinggi sulit bagi Padang untuk mendapatkan informasinya, maka diadakanlah pertemuan dengan Dt. Majo Labih Maninjau untuk mendirikan Muhammadiyah di Padang. Kemudian dilakukan musyawarah di Padang pada hari jum'at tanggal 20 Mei 1928 bertempat di toko Dt. Basa Bandaro ayah Engku Marzuki Yatim, rapat dihadiri sebanyak 20 orang.

Setelah itu diadakan rapat ke-2 di Andalas hari jum'at pada tanggal 2 Juni 1928 bertempat di rumah Ibrahim yang dihadiri oleh Sy St. Mangkuto dengan agenda acara kursus serta menentukan peresmian group ranting. Rapat menghasilkan keputusan untuk mengadakan rapat berikutnya tanggal 19 Juni 1928 di Parak Jigarang dengan agenda rapat meresmikan group serta menambah group yaitu Ketaping dan Kalumbuk. Sesudah group (ranting) diresmikan maka dikirimkanlah susunan kepengurusan ke Yogyakarta. Kemudian datanglah balasan dari H.B. Yogyakarta menjadi Verloves cabang Padang Panjang dengan cabang-cabang yaitu Maninjau, Bukit Tinggi, Padang Panjang, dan Padang.

\section{Pengertian Pengelolan}

Secara bahasa dalam Kamus Umum Bahasa Indonesia, pengelolaan berarti: Proses, cara, perbuatan mengelola; Proses melakukan kegiatan tertentu dengan menggerakkan tenaga orang lain; Proses yang membantu merumuskan kebijaksanaan dan tujuan organisasi; Proses yang memberikan pengawasan pada semua hal yang terlibat dalam pelaksanaan kebijaksanaan dan pencapaian tujuan (Poerwadarminta, 2002:411). Menurut para ahli pengelolaan berasal dari kata kelola yang berarti selenggara. Jadi pengelolaan/manajemen adalah "Kemampuan atau keterampilan untuk memperoleh hasil dalam rangka mencapai tujuan tertentu dengan cara menggerakkan orang lain" (Hamalik, 1993:7). Manajemen merupakan istilah lain dari kata pengelolaan, pengurusan, ketatalaksanaan dan lain sebagainya. Manajeman mengandung tiga pengertian, yaitu "Manajeman sebagai suatu proses, manajemen sebagai kolektivitas orang-orang yang melakukan aktivitas manajeman, dan manajemen sebagai suatu seni atau sebagai ilmu."

Menurut Hasibuan, manajemen adalah ilmu dan seni mengatur proses pemanfaatan sumber daya manusia dan sumber-sumber lainnya secara efektif dan efisien untuk mencapai suatu tujuan tertentu (Hasibuan, 2009:1). Sementara menurut Johnson seperti yang dikutip oleh Made Pidarta, manajemen ialah proses mengintegrasikan sumber-sumber yang tidak berhubungan menjadi sistem total untuk menyelesaikan suatu tujuan. Yang dimaksud sumber disini ialah mencakup orang-orang, alat-alat, media bahan-bahan, uang, dan sarana. Semuanya diarahkan dan dikoordinasikan agar terpusat dalam rangka menyelesaikan tujuan (Pidarta, 2004:3). Berdasarkan kutipan di atas akan tampak pada tiga pokok penting dalam pengertian manajemen, yaitu adanya tujuan yang ingin dicapai, tujuan yang ingin dicapai tersebut menggunakan orang lain dan kegiatankegiatan orang lain itu harus dibimbing dan diawasi. Bila definisi di atas dikaitkan dengan dunia pendidikan, maka akan terdapat sebuah istilah yaitu manajemen pendidikan.

Istilah manajemen pendidikan pada dasarnya tidak berbeda dengan manajemen lainnya seperti manajemen perusahaan, manajemen dalam suatu organisasi dan lain sebagainya, yang berbeda adalah objek yang dimenej yaitu bidang pendidikan, dimana bidang pendidikan lebih komplek daripada bidang lainnya, karena melibatkan banyak orang, banyak unsur dan berbagai sumber daya. 
Manajemen pendidikan merupakan suatu tindakan manajemen yang bertujuan untuk mengatur, mengelola, membimbing, mengarahkan, dan mengawasi setiap aktivitas manajemen yang dilakukan orang-orang yang tergabung dalam organisasi pendidikan dalam rangka mencapai tujuan pendidikan itu sendiri. Tujuan pendidikan yang dimaksud disini sangat beragam baik tujuan pendidikan pada tingkat nasional, institusi sekolah, sampai tujuan kurikulum. Pencapaian semua tujuan di atas dalam aktivitas manajemen ditujukan pada peningkatan mutu atau kualitas pendidikan.

Sedangkan peningkatan kualitas pendidikan merupakan masalah yang sangat rumit dimana dipengaruhi banyak faktor, salah satu diantaranya adalah faktor manajemen itu sendiri, sehingga manajemen pendidikan merupakan salah satu faktor yang amat penting untuk diperhatikan, dibenahi, dan dilaksanakan dengan sebaik-baiknya dalam rangka meningkatkan mutu pendidikan tersebut. Berdasarkan beberapa pendapat yang telah dikemukakan di atas dapat diambil suatu kesimpulan bahwa pengelolaan SD Muhammadiyah di kota Padang atau lebih dikenal dengan manajemen, adalah kemampuan atau keterampilan pengelola dalam mengelola kurikulum, tenaga kependidikan, kesiswaan, husemas, dan sarana prasarana dengan cara memanfaatkan segala sumber daya yang tersedia dalam rangka mencapai tujuan secara efeketif dan efisien.

\section{Sekolah Dasar Muhammadiyah}

SD Muhammadiyah adalah jalur pendidikan formal. Pada dasarnya tidak ada perbedaan antara SD Muhammadiyah dengan SD Negeri atau Swasta lainnya. Jika di tinjau dari status maupun tujuannya sama dalam hal: Perlunya membangun gedung, mengangkat guru, proses belajar melalui tatap muka dan kalsikal, guru mata pelajaran, sumber belajar utama berupa buku paket, ulangan harian (sumatif dan formatif), terikat oleh waktu dan tempat secara ketat (Depdikbud, 1997:65). Dari pengertian di atas dapat disimpulkan bahwa SD Muhammadiyah secara teknis dan operasional pada umumnya sama dengan SD Negeri atau Swasta lainnya, namun yang menjadi perbedaannya adalah bahwa SD Muhammadiyah kelola oleh Muhammadiyah c.q. bagian Majelis Pendidikan Sekolah Dasar dan Menengah. Selanjutya, kedudukannya dalam Sistem Pendidikan Nasional mempunyai strata yang sama dengan SD lainnya. Dengan kata lain titik berat SD Muhammadiyah ditekankan pada pengelolaan dua unsur yaitu Dinas Pendidikan Nasional dan Muhammadiyah c.q. bagian Majlis Pendidikan Dasar Dan Menengah.

Selanjutnya, pengelolan Sekolah Dasar Muhammadiyah seperti di atas, terbeban kepada bagian Majelis Pendidikan Sekolah Dasar dan Menengah yang selanjutnya disingkat dengan Dikdasmen. Kata pengelolaan diartikan sama dengan kata manajemen. Sedangkan menurut Arikunto pengelolaan meliputi banyak kegiatan dan kesemuanya itu bersama-sama menghasilkan suatu hasil akhir, yang memberikan informasi bagi penyempurnaan per-kegiatan (Arikunto, 1997:8). Selanjutnya, kegiatan pengelolaan sekolah meliputi pengelolaan kurikulum, tenaga kependidikan, kesiswaan, keuangan, sarana dan prasarana, husemas, dan pengelolaan layanan khusus (Mulyasa, 2003:39). Sekaitan dengan sarana dan prasarana, proses belajar mengajar atau kegiatan belajar mengajar (PBM) akan semakin sukses bila ditunjang dengan sarana dan prasarana pendidikan yang memadai, sehingga pemerintah pun selalu berupaya untuk secara terus menerus melengkapi sarana dan prasarana pendidikan bagi seluruh jenjang dan tingkat pendidikan. Sarana dan prasarana pendidikan disebut juga dengan fasilitas atau bendabenda pendidikan, dalam pengelolaan fasilitas pendidikan tersebut berdasarkan tanggung jawab yang tinggi. 
Fasilitas atau benda-benda pendidikan dapat ditinjau dari fungsi, jenis atau sifatnya (Gunawan, 2011:115). Ditinjau dari fungsinya terhadap PBM, prasarana pendidikan berfungsi tidak langsung (kehadirannya tidak sangat menentukan). Adapun yang termasuk sarana dan prasarana dari fungsinya terhadap PBM adalah tanah, halaman, pagar, tanaman, gedung/bangunan sekolah, jaringan jalan, air, listrik, telepon, serta perabot/mobiler. Sedangkan sarana pendidikan berfungsi langsung (kehadirannya sangat menentukan) terhadap PBM, seperti alat pelajaran, alat peraga, alat praktek dan media pendidikan. Jika ditinjau dari jenisnya, fasilitas pendidikan dapat dibedakan menjadi fasilitas fisik dan fasilitas non fisik. Adapun fasilitas fisik atau fasilitas material yaitu segala sesuatu yang berwujud benda mati atau dibendakan yang mempunyai peran untuk memudahkan atau melancarkan sesuatu usaha, seperti kendaraan, mesin tulis, komputer, perabot, alat peraga, model, media, dan sebagainya.

Selanjutnya, fasilitas non fisik yakni sesuatu yang bukan benda mati, atau kurang dapat disebut benda atau dibendakan, yang mempunyai peranan untuk memudahkan atau melancarkan sesuatu usaha seperti manusia, jasa, uang. Kemudian, jika ditinjau dari sifat barangnya, benda-benda pendidikan dapat dibedakan menjadi barang bergerak dan barang tidak bergerak, yang kesemuanya dapat mendukung pelaksanaan tugas. Adapun barang bergerak atau barang berpindah/dipindahkan dikelompokkan menjadi barang habis pakai dan barang tak habis pakai. Selanjutnya, barang habis pakai ialah barang yang susut volumenya pada waktu dipergunakan, dan dalam jangka waktu tertentu barang tersebut dapat susut terus sampai habis atau tidak berfungsi lagi, seperti kapur tulis. tinta, kertas, spidol, penghapus, sapu dan sebagainya. Sedangkan barang tak habis pakai ialah barang-barang yang dapat dipakai berulang kali serta tidak susut volumenya semasa digunakan dalam jangka waktu yang relatif lama, tetapi tetap memerlukan perawatan agar selalu siap pakai untuk pelaksanaan tugas, seperti mesin tulis, komputer, mesin stensil, kendaraan, perabot, media pendidikan dan sebagainya. Selanjutnya, barang tidak bergerak ialah barang yang tidak berpindah-pindah letaknya, seperti tanah, bangunan/gedung, sumur dan sebagainya. Berdasarkan uraian ini, dapat disimpulkan bahwa pengelolaan sarana dan prasarana SD Muhammadiyah di kota Padang meliputi kegiatan, yaitu pengadaan media pembelajaran, dan pengadaan fasilitas.

\section{Jenis Penelitian}

\section{METODOLOGI PENELITIAN}

Jenis penelitian ini adalah penelitian deskriptif karena penelitian ini tertuju kepada pengungkapan masalah yang terjadi pada masa sekarang dan sebagaimana adanya. Penelitian ini mendeskripsikan tentang Pengelolaan Sekolah Dasar Muhammadiyah di Kota Padang dilihat dari Pengelolaan Sarana dan Prasarana.

\section{Populasi dan Sampel}

Pada Penelitian ini yang menjadi populasinya adalah seluruh guru kelas yang terdiri dari kelas 1 sampai kelas V1 dan guru Agama Islam yang mengajar di Sekolah Dasar Muhammadiyah di Kota Padang yang berjumlah 77 Orang. Karena terbatasnya jumlah populasi, maka tidak dilakukan penarikan sampel oleh sebab itu penelitian ini adalah penelitian populasi. Untuk lebih jelasnya dapat dilihat pada tabel berikut ini : 
Tabel 1.: Jumlah Guru SD Muhammadiyah Kota Padang

\begin{tabular}{|l|l|l|} 
No & Nama Sekolah & Jumlah \\
\hline 1 & SD Muhammadiyah I Marapalam Kecamatan Padang Timur & 7 Orang \\
\hline 2 & SD Muhammadiyah IV Simp. Haru kecamatan Padang Timur & 7 Orang \\
\hline 3 & SD Muhammadiyah 05 Ketaping Kecamatan Kuranji & 7 Orang \\
\hline 4 & SD Muhammadiyah VII Air Mati Kecamatan Padang Timur & 7 Orang \\
\hline 5 & SD Muhammadiyah XI Abdul Muis Kecamatan padang Timur & 7 Orang \\
\hline 6 & SD Muhammadiyah Surau Gadang Kecamatan Nanggalo & 7 Orang \\
\hline 7 & SD Muhammadiyah Kurao Pagang Kecamatan Nanggalo & 7 Orang \\
\hline 8 & SD Muhammadiyah Berok Kecamatan Nanggalo & 7 Orang \\
\hline 9 & SD Plus Aisyiyah I Kecamatan Nanggalo & 7 Orang \\
\hline 10 & SD Muhammadiyah X Alai Kecamatan Padang Utara & 7 Orang \\
\hline 11 & SD Muhammadiyah IX Gaung Kecamatan Lubuk Begalung & 7 Orang \\
\hline & Jumlah & 77 Orang \\
\hline
\end{tabular}

Sumber: Data Survey Lapangan.

\section{Variabel Penelitian}

Variabel penelitian ini terdiri dari satu variabel yaitu tentang Pengelolaan Sekolah Dasar Muhammadiyah di Kota Padang, khususnya mengenai Pengelolaan sarana dan prasarana, indikatornya yaitu pengadaan media pembelajaran dan pengadaan fasilitas belajar.

\section{Instrumen Penelitian}

Dalam penelitian ini peneliti melakukan penelitian dengan menggunakan angket, yaitu alat pengumpulan data berupa sejumlah pertanyaan tertulis yang harus dijawab pula secara tertulis oleh responden untuk memperoleh berbagai keterangan yang diperlukan peneliti. Bentuk angket yaitu dirumuskan dalam bentuk skala likert dengan menggunakan lima alternativ jawaban, yaitu Selalu (SL). Sering (SR), Kadang ( KD), Jarang (JR), dan Tidak Pernah (TP).

Langkah-langkah dalam penyusunan angket adalah:

1. Membuat kisi-kisi angket dengan cara:

a. Menetapkan variabel yang akan diteliti

b. Menentukan sub variabel dari masing-masing variabel

c. Menentukan indikator dari masing-masing sub variabel

d. Menentukan sub indikator dari masing-masing indikator

2. Melakukan uji coba dan analisis, hasil uji coba tersebut untuk mengetahui apakah pertanyaan angket dapat dimengerti, dipahami dan dijawab oleh responden. Uji coba angket tersebut dilaksanakan pada 30 orang guru pada Sekolah Dasar Islam Terpadu (SDIT) di Kota Padang yang terdiri dari SDIT Sabhisma, SDIT Budi Mulia, SDIT Khaira Ummah, SDIT Marhamah. Uji coba dilakukan pada sekolah ini sehubungan sekolah tersebut memiliki karakteristik yang tidak jauh berbeda, baik pada letak georafis maupun sumber daya yang tesedia.

3. Menganalisis hasil uji coba untuk mengetahui validitas dan reabilitas angket, dengan menggunakan skala Gutmant.

Untuk mengungkapkan hasil dari penelitian ini berpedoman pada gambaran tingkat kualifikasi seperti di bawah ini (Riduwan, 2002:15). 
Tabel 2:Tingkat Kualifikasi dan Persentase Penilaian Penelitian

Kualifikasi

\begin{tabular}{l|l}
\hline Sangat baik & $81-100 \%$ \\
\hline Baik & $61-80 \%$ \\
\hline Cukup & $41-60 \%$ \\
\hline Kurang & $21-40 \%$ \\
\hline Sangat kurang & $0-20 \%$ \\
\hline
\end{tabular}

Teknik Analisis Data

Teknik analisis data dengan menggunakan statistik deskriptif yang menggunakan tabulasi frekuensi.

Tabel 3: Angket Pengelolaan Sarana dan Prasarana

$\begin{array}{llllll}\text { PERNYATAAN } & \text { SL } & \text { SR } & \text { KD } & \text { JR } & \text { TP }\end{array}$

\section{Pengelolaan Sarana dan Prasarana}

1. Kepala sekolah mendukung memperhatikan kebutuhan guru akan alat-alat tulis yang diperlukan dalam membuat persiapan mengajar

2. Kepala sekolah memperhatikan kebutuhan guru akan buku pelajaran dan alat peraga yang diperlukan dalam proses pembelajaran

3. SD Muhammadiyah menggunakan radio, tape recorder dan OHP untuk mendukung kepentingan pengajaran

4. Perpustakaan SD Muhammadiyah dilengkapi dengan buku teks pelajaran yang cukup lengkap sehingga mendukung tugas guru untuk meningkatkan kualitas belajar siswa

5. Penggunaan komputer di SD Muhammadiyah mendukung kinerja guru dan proses pembelajaran

6. Penggunaan telepon di SD Muhammadiyah mendukung kinerja guru untuk meningkatkan prestasi belajar siswa

7. SD Muhammadiyah menggunakan ruangan UKS untuk mendukung kesehatan siswa

8. SD Muhammadiyah menggunakan Mushalla untuk mendukung ibadah warga sekolah

9. SD Muhammadiyah menggunakan lapangan olah raga untuk mendukung proses pembelajaran siswa

Sumber: Data Diolah. 


\section{Menghitung Frekuensi Jawaban}

Setelah angket diperiksa, untuk mengetahui hasilnya maka yang harus dilakukan adalah menghitung frekuensi dari jawaban responden. Mengitung frekuensi jawaban responden dapat dilakukan dengan dua cara yaitu pertama melalui uji validitas, kedua reliabilitas.

a) Uji validitas butir instrumen (data uji coba)

Validitas instrumen dihitung menggunakan analisis statistik korelasi product moment, dengan cara mengkorelasikan antara skor setiap butir instrumen dengan skor total setiap subjek. Hasil perhitungan uji validitas, diperoleh korelasi butirbutir pernyataan yang memenuhi persyaratan untuk dianalisis sebagai data penelitian, adalah pernyataan yang mempunyai korelasi $(r)>0.361$ pada taraf signifikansi $\alpha 0.05$, sedangkan pernyataan yang mempunyai korelasi $<0.361$, tidak digunakan dalam analisis data penelitian (Hadi, 2004:23). Berdasarkan analisis diperoleh butir pernyataan yang dapat digunakan sebanyak 9 butir

b) Reliabilitas instrumen penelitian (data uji coba)

Untuk memperoleh reliabilitas instrumen penelitian, digunakan metoda belah dua (split-half method), dengan asumsi bahwa butir pernyataan yang genap maupun ganjil adalah homogen dan mengukur hal yang sama. Untuk menghitung tingkat reliabilitas digunakan formulasi korelasi Product Moment. Butir-butir pernyataan dibagi menjadi dua belahan. Belahan pertama bernomor ganjil dan belahan ke dua bernomor genap. Kemudian skor masing-masing pernyataan dijumlahkan. Selanjutnya dikorelasikan antara ke dua belahan tersebut. Hasil ini baru mengetahui reliabilitas setengah test, dilanjutkan dengan rumus Spearman Brown, maka diperoleh angka korelasi yang menyatakan tingkat reliabilitas suatu test. Hasil perhitungan reliabilitas instrumen penelitian adalah sebesar $0.971>\mathrm{r}_{\text {tab }} 0.361$.

\section{HASIL DAN PEMBAHASAN}

\section{Deskripsi Data Penelitian}

Sebelum dilakukan analisis data dengan menggunakan statistik deskriptif, maka terlebih dahulu dilakukan verifikasi data dan uji instrument penelitian. Verifikasi data bertujuan untuk mengetahui kelengkapan data, sehingga dapat ditetapkan data bisa diolah lebih lanjut atau tidak. Data yang bisa diolah adalah bila responden mengikuti petunjuk pengisian angket dan mengisi semua butir angket yang dinyatakan. Berdasarkan hasil verifikasi data dari jumlah responden pada penelitian ini sebanyak 30 orang yang diberikan angket, setelah diperiksa angket dapat dikembalikan seluruhnya. Artinya dari 30 responden penelitian semua data dapat diolah lebih lanjut.

Uji instrumen penelitian dimaksudkan untuk mengetahui validitas dan reliabelitas data penelitian. Instrumen yang baik harus memenuhi dua persyaratan penting yaitu valid dan reliable. Suatu angket dikatakan valid apabila item pernyataan pada angket tersebut mampu mengungkapkan sesuatu yang akan diukur oleh angket tersebut sedangkan suatu angket dikatakan reliabel bila jawaban terhadap pernyataan adalah konsisten atau stabil dari waktu ke waktu.

Instrumen penelitian ini menggunakan uji coba diluar sampel, yaitu dimana instrumen penelitian diberikan kepada subjek di luar populasi penelitian. Dengan ketentuan apabila data ujicoba memenuhi persyaratan uji validitas dan reliabilitas, maka data penelitian dapat dinyatakan valid tanpa melakukan uji validitas dan reliabelitas lagi. 


\section{Analisis Data}

Analisis data dalam penelitian ini menggunakan analisis deskriptif, yang bertujuan untuk memberikan gambaran secara umum distribusi frekuensi masing-masing variabel penelitian. Dalam deskripsi ini disajikan distribusi variabel sarana dan prasarana dalam pengelolaan SD Muhammadiyah di kota Padang. Jelasnya dapat dilihat pada tabel berikut:

Tabel 4:

Jawaban Berdasarkan Tingkat Klasifikasi dan Distribusi Data Penelitian Statistik Analisis

Sarana dan

Prasarana

\begin{tabular}{|c|c|c|}
\cline { 2 - 3 } & F & \% \\
\hline Selalu (SL) & 241 & 39.1 \\
\hline Sering (SR) & 119 & 19.3 \\
\hline Kadang-Kadang (KD) & 117 & 19.0 \\
\hline Jarang (JR) & 45 & 7.3 \\
\hline Tidak Pernah (TP) & 94 & 15.3 \\
\hline Responden & \multicolumn{2}{|c}{77} \\
\hline Jumlah Item & \multicolumn{2}{|c}{8.60} \\
\hline Mean & \multicolumn{2}{|c}{3.4} \\
\hline Median & \multicolumn{2}{|c}{1.45} \\
\hline Std Dev & \multicolumn{2}{|c}{2.09} \\
\hline Variance & \multicolumn{2}{|c}{1} \\
\hline Min & \multicolumn{2}{|c}{5} \\
\hline Max
\end{tabular}

Sumber: Data Diolah.

Penyajian data atas jawaban responden terhadap variabel sarana dan prasrana dalam bentuk distribusi frekuensi dapat dilihat pada tabel 2 di atas, dimana masing-masing responden memberikan penilaian jawaban terhadap pernyataan sesuai dengan pendapatnya. Jumlah item pernyataan pada variabel sarana dan prasarana sebanyak 8 butir pernyataan valid. Hasil perhitungan menunjukkan bahwa frekuensi selalu $(\mathrm{SL})=241$ atau $39.1 \%$, frekuensi sering $(\mathrm{SR})=119$ atau $19.3 \%$, frekuensi kadang-kadang $(\mathrm{KD})=117$ atau $19 \%$, frekuensi jarang $(\mathrm{JR})=45$ atau $7.3 \%$ dan frekuensi tidak pernah $=94$ atau 15.3\%. Rerata hitung $($ mean $)=3.60$, median $=4$, standar deviasi $=1.45$, variance $=2.09$, nilai minimum $=1$ dan nilai maksimum $=5$. Berikut ini digambarkan histogram frekuensi variabel sarana dan prasarana; 


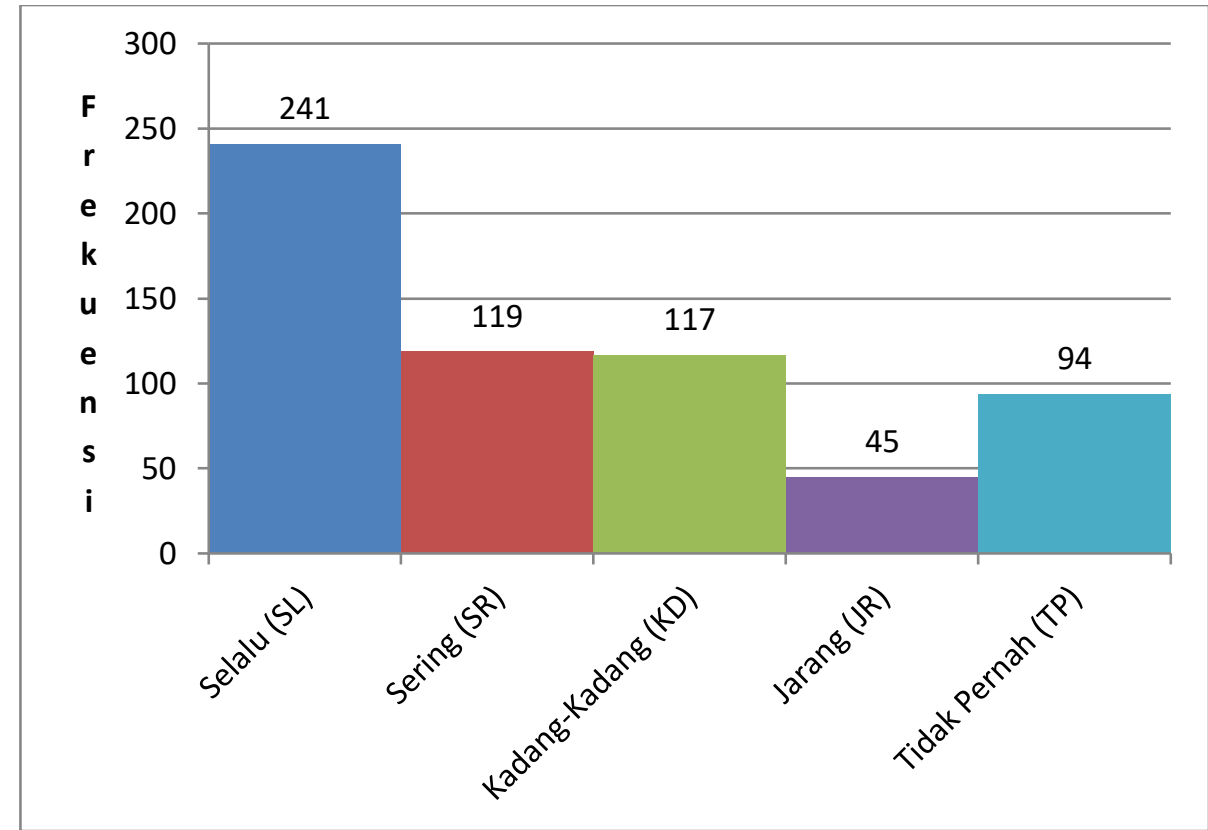

Gambar 1. Histogram Distribusi Frekuensi Variabel Sarana dan Prasarana

Sesuai data yang dikumpulkan dari 8 item pernyataan mewakili indikator sarana dan prasarana dalam tinjauan pengelolaan SD Muhammadiyah di kota Padang masing-masing responden diperoleh penyebaran jawaban berdasarkan tingkat klasifikasi sebagai berikut, klasifikasi selalu (SL) frekuensi 241 atau 39.1\%, klasifikasi sering (SR) frekuensi 119 atau 19.3\%, klasifikasi kadang-kadang frekuensi 117 atau 19\%, klasifikasi jarang (JR) frekuensi 45 atau $7.3 \%$ dan klasifikasi tidak pernah frekuensi 94 atau 15.3\%. Berdasarkan data di atas, maka persentase ketercapaian skor untuk indikator sarana dan prasarana yaitu :

$$
(94 \times 1)+(45 \times 2)+(117 \times 3)+(119 \times 4)+(241 \times 5)
$$

= ---------------- $\times 100 \%$

$$
(5 \times 77 \times 8)
$$$$
=2216 / 3080 \times 100 \%=72.42 \% \text {. }
$$

Artinya kriteria interpretasi skor yang diperoleh berada pada klasifikasi baik. Jelasnya dapat dilihat pada tabel berikut:

Tabel 5:

Persentase Tingkat Ketercapaian Skor Sarana dan Prasarana

No

\section{Klasifikasi}

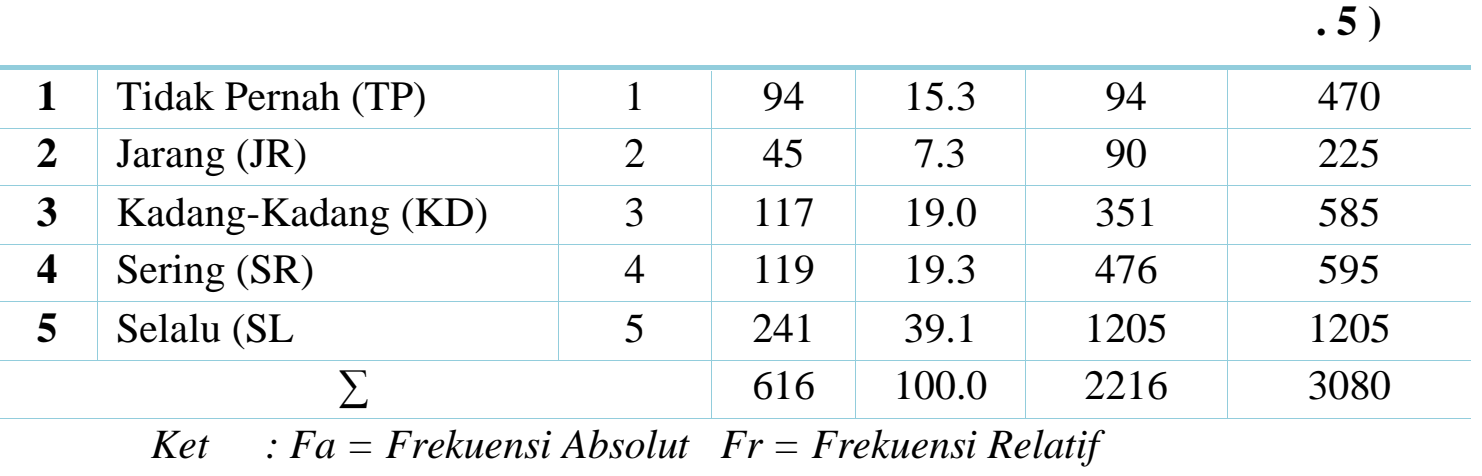




\section{Pembahasan}

Berdasarkan analisis data di atas, selanjutnya dilakukan pembahasan tentang hasil penelitian yang telah dilaksanakan. Pembahasan ini berguna untuk memudahkan dalam menarik kesimpulan dan mengemukakan saran-saran yang relevan. Adapun pembahasan dari penelitian ini sebagai berikut: Sesuai data yang dikumpulkan dari 8 item pernyataan mewakili indikator sarana dan prasarana dalam tinjauan pengelolaan SD Muhammadiyah di Kota Padang masing-masing responden diperoleh penyebaran jawaban berdasarkan tingkat klasifikasi sebagai berikut, klasifikasi selalu (SL) frekuensi 241 atau 39.1\%, klasifikasi sering (SR) frekuensi 119 atau 19.3\%, klasifikasi kadang-kadang frekuensi 117 atau 19\%, klasifikasi jarang (JR) frekuensi 45 atau 7.3\% dan klasifikasi tidak pernah frekuensi 94 atau $15.3 \%$. $72.42 \%$. Artinya kriteria interpretasi skor yang diperoleh berada pada klasifikasi baik.

Berdasarkan persentase di atas bahwa pengelolaan sarana dan prasarana sekolah dasar Muhammadiyah di Kota Padang baik. Secara angket itulah hasilnya, namun di lapangan lain yang terjadi, masih banyak sekolah dasar Muhammadiyah yang sangat memprihatinkan dari segi sarana dan prasarana yang ada. Selama ini sekolah dasar Muhammadiyah menjalankan aktifitas pendidikannya dengan segala kekurangannya di antaranya dari segi gedung yang tidak representatif, wc yang tidak memadai, kursi dan meja yang kurang, media yang kurang lengkap, masih banyak lagi sarana dan prasarananya yang tidak terpenuhi. Hal ini terjadi karena kurangnya kepedulian lembaga terkait akan kondisi sekolah dasar Muhammadiyah di Kota Padang, untuk berkembangnya secara baik sekolah dasar Muhammadiyah di Kota Padang untuk masa yang akan datang, sangat diperlukan sekali perhatian dan kerjasama semua lembaga yang berwenang.Sarana pendidikan adalah peralatan dan perlengkapan yang secara langsung digunakan dan menunjang proses pendidikan, khususnya proses belajar mengajar seperti: gedung, ruang kelas, meja kursi, serta alat-alat dan media pengajaran.

Ditinjau dari fungsi atau peranannya terhadap pelaksanaan proses belajar mengajar, maka sarana pendidikan dapat dibedakan menjadi 3 macam, yaitu: Alat pelajaran; alat peraga; dan media pengajaran. Alat pelajaran adalah alat yang digunakan secara langsung dalam proses belajar mengajar. Alat ini mungkin berwujud buku, alat peraga, alat tulis dan alat praktek. Sedangkan alat peraga adalah alat bantu pendidikan dan pengajaran dapat berupa perbuatan-perbuatan atau benda-benda yang sudah memberi pengertian kepada anak didik berturut-turut dari yang abstrak hingga yang konkrit. Selanjutnya, media pendidikan adalah sarana pendidikan yang digunakan sebagai perantara dalam proses belajar mengajar untuk lebih mempertinggi efektifitas dalam mencapai tujuan pendidikan.

Dalam Undang-Undang Sistem Pendidikan Nasional Nomor 20 Tahun 2003 menyatakan dalam pasal 45 bahwa sarana prasarana pendidikan, yaitu:

1. Setiap satuan pendidikan formal dan non formal menyediakan sarana dan prasarana yang memenuhi keperluan pendidikan sesuai dengan pertumbuhan dan perkembangan potensi fisik, kecerdasan intelektual, sosial, emosional, dan kejiwaan peserta didik.

2. Ketentuan mengenai sarana dan prasarana pendidikan pada semua pendidikan sebagaimana dimaksud dalam ayat (1) diatur lebih lanjut dengan peraturan pemerintah $(\mathrm{PP})^{1}$

${ }^{1}$ Undang-Undang Sistem Pendidikan Nasional Nomor 20 tahun 2003, (Jakarta: Siar Grafika, 2006), h. 23 


\section{Kesimpulan}

\section{KESIMPULAN DAN SARAN}

Berdasarkan hasil analisis data dan pengujian hipotesis dari angket yang disebarkan kepada 77 responden dari 11 SD Muhammadiyah di Kota Padang maka diperoleh data bahwa Pengelolaan sarana dan prasarana pada SD Muhammadiyah di Kota Padang baik. Akan tetapi, berdasarkan fakta di lapangan, penulis mendapatkan bahwa pengeloaan sarana dan prasarana pada SD Muhammadiyah kurang baik. Hal ini berdasarkan fakta dilapangan bahwa banyak sekali sarana dan prasarana pada SD Muhammadiyah di Kota Padang yang harus diperbaiki, di antaranya adalah bangunan yang kurang layak dipakai untuk belajar, lokal belajar yang sangat minim, meja, kursi dan media belajar yang terdapat di dalam setiap lokal tidak memadai, ruang perpustakaan tidak ada, Water Closed (WC) yang tidak layak pakai, dan ruangan kantor yang tidak memadai. Jadi, berdasarkan fakta dan realita tersebut dapat disimpulkan bahwa pengelolaan sarana dan prasarana pada SD Muhammadiyah di Kota Padang kurang baik.

\section{Saran}

Berdasarkan kesimpulan di atas, maka saran yang dapat diajukan adalah diharapkan pengelolaan sarana dan prasarana pada SD Muhammadiyah di Kota Padang ditingkatkan dengan cara bekerjasama dengan masyarakat dan pihak-pihak tertentu untuk kemajuan pendidikan Islam di masa yang akan datang.

\section{DAFTAR REFERENSI}

Arikunto, Suharsimi.1997. Prosedur Penelitian. Jakarta: Rineka Cipta

Depdikbud. 1997. Pedoman Administrasi Sekolah Dasar. Jakarta: Balai Pustaka.

Gunawan, H. Ary. 2011. Administrasi Sekolah. Jakarta: Rineka Cipta.

Hadi, Sutrisno. 2004. Metodologi Research Jilid III. Jogyakarta: Fakultas Psikologi UGM

Hamalik, Oemar. 1993. Psikologi Manajemen. Bandung: Trigenta Karya

Hasibuan, S.P. Malayu. 2009. Manajemen Sumber Daya Manusia. Jakarta: Bumi Aksara

Mulyasa. 2003. Manajemen Berbasis Sekolah. Bandung: Remaja Rosdakarya.

Pidarta, Made. 2004. Manajemen Pendidikan Indonesia. Jakarta: Rineka Cipta

Poerwadarminta, WJS. 2002. Kamus Umum Bahasa Indonesia. Jakarta: Balai Pustaka

Riduwan. 2002. Skala Pengukuran Variabel-variabel Penelitian. Bandung: Alfa Beta

Wibowo, Basuki, dkk. 1992. Media Pengajaran. Jakarta: Depdikbud

Yunus, Mahmud. 1930. Sejarah Pendidikan Islam di Indonesia. Jakarta: Hidakarya Agung. 